\title{
Pesan kegagalan dalam novel Marchella F.P melalui hermeneutika interpretasi Paul Ricouer
}

\author{
Aufa Athaya ${ }^{1}$ \\ Dewi K. Soedarsono ${ }^{2}$ \\ ${ }^{1,2}$ Program Studi Ilmu Komunikasi, Fakultas Komunikasi dan Bisnis, \\ Universitas Telkom \\ 1'aufathayaaa@gmail.com² soedarsonodewik@gmail.com
}

\begin{abstract}
ABSTRAK
Nanti Kita Cerita Tentang Hari Ini (NKCTHI) merupakan salah satu karya sastra dalam bentuk novel yang dikemas dalam bentuk kalimat-kalimat sederhana dengan diksi dan desain grafis yang menarik. NKCTHI merupakan novel dengan genre self healing yang berisi tentang solusi dari permasalahan-permasalahan yang banyak orang alami dalam kehidupan sehari-hari. Tujuan dilakukannya penelitian ini adalah untuk mengetahui adakah kesamaan pemahaman makna antara penulis dari buku tersebut dengan pembacanya. Penelitian ini dilakukan dengan metode penelitian kualitatif dan menggunakan paradigma fenomenologi. Dalam mendapatkan data yang kredibel peneliti melakukan penafsiran terhadap novel NKCTHI untuk mengetahui makna kegagalan. Hasil penelitiannya adalah (1) Langkah Simbolik, Gambar yang ada memudahkan proses penafsiran karena menggambarkan situasi pada kalimat yang berada di sebelahnya. (2) Pemberian Makna, Tergiringnya emosi seorang pembaca novel NKCTHI dikarenakan adanya penggunaan diksi yang tepat. (3) Langkah Filosofis, Penggunaan bahasa dan gaya penulisan yang ringkas akan memudahkan proses penafsirkan makna.
\end{abstract}

Kata Kunci: Pemahaman makna, Hermeneutika Interpretasi, Fenomenologi, Analisis, Novel

\begin{abstract}
Nanti Kita Cerita Tentang Hari Ini (NKCTHI) is one of the literary works in the form of novels which are packaged in the form of simple sentences with interesting diction and graphic design. NKCTHI is a novel with self healing genre that contains solutions to problems that many people experience in daily life. The purpose of this study is to find out whether there is a common understanding of meaning between the author of the book and the reader. This research was conducted with qualitative research methods and using the phenomenology paradigm. In obtaining credible data the researcher interpreted the NKCTHI novel to find out the meaning of it. The results of the study are (1) Symbolic Steps, Existing images ease the process of interpretation because they describe the situation in the sentence next to it. (2) Giving Meanings, The emotion of an NKCTHI novel reader is happened due to the use of the correct diction. (3) Philosophical Steps, Use of language and concise writing style will ease the process of interpreting meaning.
\end{abstract}




\section{Keywords: Understanding of meaning, Hermeneutics Interpretation, Phenomenology, Analysis, Novel}

PENDAHULUAN

Novel merupakan salah satu bentuk dari karya sastra yang berisi tentang kumpulan kalimat panjang yang mengandung rangkaian cerita yang berisi tentang kehidupan seseorang ataupun tentang cerita fiksi imanjinasi dari seorang penulis. Beberapa tahun kebelakang sebelum adanya trend untuk mempromosikan novel yang diterbitkan pada sosial media tak sedikit novel yang tak laku dipasaran. Berkurangnya minat remaja untuk membaca buku fisik menjadi faktor dari novel NKCTHI untuk melakukan inovasi dan juga pra reset isi novelnya pada Instagram.

Nanti Kita Cerita Tentang Hari Ini (NKCTHI) adalah salah satu karya sastra dalam bentuk novel yang dikemas dalam kalimat-kalimat sederhana yang dipadukan dengan gambar-gambar sederhana yang menggambarkan situasi kalimat-kalimat di sampingnya. Hal tersebut menjadi daya tarik tersendiri untuk pembaca dari buku tersebut. NKCTHI dikemas dalam format artbook yang saat ini sedang banyak digemari oleh kalangan millenials Indonesia. Novel yang berangkat dari tulisan-tulisan pendek sang penulis yang dituang dalam salah satu platform sosial media yaitu, Instragram. Novel ini mengangkat self healing sebagai genrenya. Menceritakan tentang permasalahan-permasalahan sederhana yang biasa dialami oleh banyak kalangan dengan selipan solusi-solusi yang solutif pada setiap tulisannya.

Novel NKCTHI sendiri berhasil menjadi salah satu novel best seller pada toko buku Gramedia. Keberhasilan novel NKCTHI terbukti karena baiknya testimoni dari pembacanya. Baiknya pemilihan kata, uniknya design grafis dan inovatifnya cara promosi novel tersebut menjadi salah satu faktor novel tersebut mudah dipahami maknanya dan memiliki angka penjualan yang cukup baik. Pemahaman makna sendiri bisa dilakukan setelah kita mendapatkan pesan yang ingin disampaikan penulis dengan metode hermeneutika.

Kata hermeneutika berasal dari bahasa Yunani, yaitu hemeneuein, yang berarti menafsirkan. Istilah Yunani berkenaan dengan kata "hermenuetik" ini diubungkan dengan nama dewa Hermes, yaitu seorang utusan yang bertugas menyampaikan pesanpesan Jupiter kepada umat manusia. Tugas Hermes menerjemahkan pesan-pesan dari dewa di Gunung Olympus itu ke dalam bahasa yang dapat dimengerti oleh manusia. Fungsi Hermes menjadi penting sebab jika terjadi kesalah-pahaman dalam menginterpretasikan pesan dewa akibatnya akan fatal bagi umat manusia. Sejak itu Hermes menjadi simbol seorang duta yang ditugasi menginterpretasikan pesan, dan berhasil tidaknya tugas itu sepenuhnya tergantung bagaimana pesana tersebut disampaikan (Sumaryono, 1999:23-24).

Salah satu tokoh hermeneutika, Paul Ricouer mengatakan bahwa hermeneutika adalah teori mengenai aturan-aturan penafsiran, yaitu penafsiran terhadap teks tertentu, atau tanda, atau simbol yang dianggap teks. Paul Ricouer bersama dengan Emilio Betti yang menganut hermeneutika kontemporer ini berpendapat bahwa " hermeneutika adalah kajian untuk menyingkapkan makna objektif dari teks-teks yang memiliki jarak ruang dan waktu dari pembaca." Selain itu ia menganggap bahwa seiringnya perjalanan 
membaca seseorang, maka nilai awal penulis akan berkurang sedikit demi sedikit untuk menjadi bahan acuan utama memahami sebuah teks. Paul yang menganut hermeneutika metodologis ini mengarahkan hermeneutika kedalam kegiatan penafsiran dan pemahaman pada sebuah teks.

\section{KAJIAN TEORETIS}

Hermeneutika Interpretasi menurut Paul Ricouer "adalah karya pemikiran yang terdiri atas penguraian makna tersembunyi dari makna yang terlihat, pada tingkat makna yang tersirat di dalam makna literer". "Simbol dan interpretasi menjadi sebuah konsep yang saling berkaitan, interpretasi muncul di mana makna jamak berada, dan di dalam interpretasilah pluralitas makna termanifestasikan" (JosefBleicher, 2003:376).

Paul menjabarkan dalam bukunya The Interpretation Theory : Discourse and The Surplus of Meaning bagaimana cara kita mendapatkan sebuah pemahaman dengan tiga cara yaitu :

a. Langkah simbolik atau pemahaman simbol-simbol

b. Pemberian makna oleh simbol serta "penggalian" yang cermat atas makna

c. Langkah filosofis, yaitu berpikir dengan menggunakan simbol sebagai titik tolaknya (Ricouer, 2003:162-164; Sumaryono, 1999:111;Faiz,2003:36).

Ketiga langkah tersebut memiliki hubungan dengan langkah pemahaman bahasa, yaitu langkah semantik, refleksif dan eksistensial atau ontologis. Maka dari itu, Paul Ricouer memberikan penegasan pada "pemahaman itu pada dasarnya cara berada atau cara menjadi". Pemahaman tersebut ditujukan untuk memberikan kesadaran bahwa hermeneutika adalah metode yang keberadaannya sejajar dengan ilmu sains.

\section{METODE PENELITIAN}

Paradigma penelitian yang digunakan dalam penelitian ini yaitu, konstruktivisme. Konstruktivisme adalah paradigma yang hadir sebagai kritik bagi paradigma positivistik. Paradigma ini, hasil penelitiannya dipengaruhi pada nilai-nilai pengetahuan yang dipegang oleh peneliti dan respondennya. Tujuan dari penelitian ini adalah untuk mencari ataupun menemukan makna dari hal-hal yang mendasar dari pengalaman hidup. Paradigma konstruktivisme ini menjelaskan bahwa sebuah realitas itu bersifat fleksibel. Peneliti yang menggunakan konstruktivisme akan mendapatkan hasil penelitian yang dapat berubah sesuai konteks ruang dan waktunya.

Penggunaan paradigma konstruktivisme dalam penelitian ini karena ingin mengamati dan juga memahami makna pesan kegagalan pada novel Nanti Kita Cerita Tentang Hari Ini (NKCTHI). Konstruktivisme lebih terasa tepat dengan keinginan peneliti untuk bisa menganalisis teks tertulis untuk mencari makna dari pesan kegagalan pada novel Nanti Kita Cerita Tentang Hari Ini (NKCTHI).

Berdasarkan paradigma yang sudah ditentukan oleh peneliti, maka metode yang digunakan dalam penelitian ini yaitu penelitian kualitatif. Metode penelitian kualitatif adalah metode penelitian yang digunakan untuk meneliti kondisi objek yang alamiah, 
dimana peneliti adalah sebagai instrumen kunci, teknik pengumpulan datanya dilakukan secara triangulasi, data yang diperoleh cenderung data kualitatif, analisis data bersifat induktif atau kualitatif, dan hasil penelitian kualitatif bersifat untuk memahami makna, memahami keunikan, mengkonstruksi fenomena, dan menemukan hipotesis (Sugiyono,2018: 9).

Pendekatan yang digunakan dalam penelitian ini yaitu, pendekatan deskriptif. Pendekatan deskriptif adalah pendekatan yang digunakan untuk menggambarkan atau menganalisa hasil penelitian tetapi tidak digunakan untuk membuat kesimpulan yang lebih luas (Sugiyono 2018:21). Pendekatan deskriptif yang digunakan bertujuan untuk mendapatkan hasil analisa yang maksimal pada subjek dan objek yang diteliti.

\section{HASIL PENELITIAN DAN PEMBAHASAN}

Setelah melakukan kegiatan penafsiran pada teks novel Nanti Kita Cerita Tentang Hari Ini (NKCTHI). Peneliti akan memberikan penjelasan mengenai hasil analisis hermeneutika dari data yang sudah di dapatkan. Peneliti menganalisis hasil berdasarkan penjabaran Paul Ricouer dalam buku The Interpretation Theory : Discourse and The Surplus Meaning untuk mendapatkan hasil analisis dalam memahami sebuah teks yang diinginkan yaitu :

1. Langkah simbolik atau pemahaman simbol-simbol

2. Pemberian makna oleh simbol serta "penggalian" yang cermat atas makna

3. Langkah filosofis, yaitu berpikir dengan menggunakan simbol sebagai titik tolaknya (Ricouer, 2003:162-164; Sumaryono, 1999:111;Faiz,2003:36).

Ketiga langkah tersebut memiliki hubungan yang erat dengan pemahaman bahasa.

Dalam penelitian ini, simbol yang dimaksud adalah simbol grafis yang terdapat pada buku Nanti Kita Cerita Tentang Hari Ini (NKCTHI). Simbol grafis yang ada pada buku Nanti Kita Cerita Tentang Hari Ini (NKCTHI) di desain langsung oleh Marchella F.P sendiri. Adanya simbol grafis dalam buku NKCTHI juga menjadi salah satu aspek yang mempengaruhi orang untuk menambah minatnya dalam membaca buku NKCTHI. Berdasarkan hasil penafsiran pada simbol yang ada pada buku NKCTHI, peneliti mendapatkan makna bahwa setiap desain grafis yang ada menggambarkan kejadian yang terjadi dan berkaitan dengan isi dari teks yang ada pada novel tersebut.

Paul Ricouer mengatakan bahwa suatu makna dapat terbongkar apabila adanya upaya untuk melakukan interpretasi terhadap sebuah teks. Menurut Paul, upaya interpretasi sendiri dapat dilakukan dengan cara menguraikan makna tersembunyi dari makna yang tersirat dan tersurat dalam sebuah karya pemikiran yang berhubungan dengan makna dari sebuah tulisan.

Dalam pemberian makna, sebuah makna tulisan dapat terungkap ketika teks tersebut menggunakan diksi yang tepat. Proses interpretasi makna dan larutnya emosi akan lebih cepat karena diksi akan mengubah dan menambah makna dari sebuah tulisan.

Dalam penelitian ini, langkah filosofis yang digunakan akan dikaitkan pada unsur penafsiran. Seperti dalam cabang ilmu filsafat yaitu, hermeneutika. Langkah 
filosofis menurut Paul yaitu sebagai proses berpikir dengan menggunakan simbol sebagai titik tolaknya. Dalam hal itu, sebuah proses berpikir dapat berjalan apabila sebuah teks menggunakan bahasa yang mudah dimengerti juga gaya penulisan yang menarik.

Peneliti juga mendapat kesimpulan bahwa beberapa keinginan penulis NKCTHI untuk pembaca dirasakan sudah berhasil tercapai. Salah satunya, Marchella memberikan simbol grafis sebagai pemanis dan juga alat untuk mempermudah pembacanya mengerti makna dari tulisannya tersebut. Keinginan tersebut tercapai karena adanya simbol grafis pada buku NKCTHI yang memudahkan pembacanya untuk memahami. Marchella juga menyampaikan bahwa buku NKCTHI disusun melalui hasil riset tentang apa saja permasalahan yang dirasakan oleh orang banyak agar pembacanya dapat merasakan hal yang sama sehingga emosinya menjadi tergiring. Hal tersebut terbukti dengan banyaknya pembaca buku NKCTHI yang emosinya tergiring ketika membacanya.

\section{SARAN}

\section{Saran Akademis}

Penelitian ini diharapkan dapat menjadi referensi bagi peneliti selanjutnya yang tertarik untuk mengangkat Filsafat Ilmu Komunikasi khususnya hermeneutika sebagai tema dari tugas akhir ataupun penelitiannya.

\section{Saran Praktis}

Berdasarkan penelitian yang telah dilakukan, peneliti menyarankan kepada Marchella selaku penulis dari buku Nanti Kita Cerita Tentang Hari Ini (NKCTHI) untuk menggunakan desain grafis atau gambar dan bahasa yang lebih mudah dimengerti dalam karya tulisnya.

\section{DAFTAR PUSTAKA}

\section{BUKU}

Azmi,Khaerul. 2013. Filsafat Ilmu Komunikasi. Tangerang : Empat Pena Publishing. Ghony, M. Djunaidi dan Fauzan Almanshur. 2012. Metode Penelitian Kualitatif. Jogjakarta : Ar-Ruzz Media.

Noor, Redyanto. 2007. Pengkajian Sastra. Semarang: Fasindo.

Nurgiyantoro, Burhan. 2013. Teori Pengkajian Fiksi. Yogyakarta: Gadjah Mada

Nursito, 2000. Ikhtisar kesusastraan Indonesia. Yogyakarta: Adicita Karya Nusa.

Sobur,Alex.Filsafat Komunikasi.2013. Bandung : PT Remaja Rosdakarya.

Sugiyono. 2018. Metode Penelitian Kualitatif. Bandung : Alfabeta.

Sumaryono,E. 1999. Hermeneutik : Sebuah Metode Filsafat. Yogyakarta : Kanisius.

W. M. Hadi, Abdul. 2004. Hermeneutika, Estetika dan Religiusitas : Esai-Esai Sastra Sufistik dan Seni Rupa. Jakarta : Matahari.

\section{SKRIPSI}


Akbar, Muhamad Taufik. 2016. Analisis Hermeneutika Teks Lagu "Pasar Bisa Diciptakan" Karya Efek Rumah Kaca. Bandung : Universitas Telkom.

Hamdani, Mahbub. 2018. Diskursus Ketuhanan Dalam Puisi Khalil Gibran (Kajian Hermeneutika Paul Ricouer) : Universitas Islam Negeri Syarif Hidayatullah Jakarta.

Muamaroh, Esti. 2016.DIALOG ISLAM DAN BARAT (Analisis Hermeneutika Derrida Atas Film 99 Cahaya Di Langit Eropa). Purwokerto: Institut Agama Islam Negeri Purwokerto.

Prasastriansyah, Andhika Widianto. 2018. Analisis Hermeneutika Teks Lagu Celengan Rindu Karya Fiersa Besari. Bandung : Universitas Telkom

Rifa'i, Imam. 2014.Hermeneutika Fenomenologi Paul Ricouer (Telaah FilosofisHistoris). Yogyakarta : Universitas Islam Negri Sunan Kalijaga.

Saputri ,Kistiriana Agustin Erry. 2012. Analisis Hermeneutik Wilhelm Dilthey dalam Puisi Du Hast Gerufen - Herr, Ich Komme Karya Friedrich Wilhelm Nietzsche. Yogyakarta :Universitas Negeri Yogyakarta.

Septiani, Fina. 2012. Konsep Religiusitas Pada Puisi-Puisi Karya Teguh Trianton Tahun 2003-2009 (Kajian Simbol Hermeneutika Paul Ricouer) : Universitas Muhammadiyah Purwokerto.

\section{JURNAL}

B.S, Abdul Wachid. 2006. Hermeneutika Sebagai Sistem Interpretasi Paul Ricoeur Dalam Memahami Teks-Teks Seni. Purwokerto.

B.S, Abdul Wachid. 1970. Puisi Sufi A. Mustofa Bisri. IBDA : Jurnal Kajian Islam dan Budaya. Purwokerto.

Darma, IN Wijaya. 2014. Imajinasi Tentang Indonesia (Studi Hermeneutik Paul Ricouer Teks Edisi Khusus 100 Tahun Kebangkitam Nasional Majalan Tempo dan Gatra). Yogyakarta.

Kafle, Narayan Prasad.2011. Hermeneutic Phenomenological Research Method Simplified. Nepal

Laverty, Susann M.. 2003. Hermeneutic Phenomenology and Phenomenology: A Comparison of Historical and Methodological Considerations. Canada.

Lestari Ummu Fatimah Ria. 2016. Ummu Fatimah Ria Lestari. "Fungsi Bangunan Dokwi Vam dan Kembu Vam Bagi Suku Yali dalam Novel Penguasa-penguasa Bumi Karya Don Richardson", Kapata Arkeologi. Papua Barat.

Lutfi, Mochtar. 2007. Hermeneutika: Pemahaman Konseptual dan Metodologis. Surabaya.

Muflihah. 2012. Hermeneutika Sebagai Metoda Interpretasi Teks Al-Qur'an. Surabaya. Nursida, Ida. 2016. Menakar Hermeneutika Dalam Kajian Sastra. Banten.

Paterson,Margo and Joy Higgs. 2005. Using Hermeneutics as a Qualitative Research Approach in Professional Practice. Canada and Sidney.

Rahayu Ratih. 2017. Interferensi dalam Cerpen di Lampung Post, Madah : Jurnal Bahasa dan Sastra. Riau.

Rennie, David L.. 2012. Qualitative Research as Methodical Hermeneutics. Toronto, Canada.

Saidi, Acep Iwan. 2008. Hermeneutika, Sebuah Cara Untuk Memahami Teks. Bandung. 
Susilowati, Tri. 2015. Transformasi Al Quran Dan Hadis Dalam Novel Biografi Muhammad: Para Pengeja Hujan Karya Tasaro Gk: Tinjauan Intertekstualitas Dan Implementasinya Pada Mahasiswa Universitas Pekalongan. Surakarta : Universitas Muhammadiyah Surakarta.

Vieira,K. A. L. and G. M. de Queiroz. 2017. Hermeneutic Content Analysis: a method of textual analysis. Germany.

\section{INTERNET}

https://www.academia.edu/18481521/HERMENEUTIKA_PAUL_RICOEUR https://www.referensimakalah.com/2012/11/pengertian-hermeneutika.html http://www.angelfire.com/journal/fsulimelight/hermen.html https://www.goodreads.com/list/show/67567.Novel_Indonesia_Terbaik https://www.gramedia.com/blog/daftar-novel-indonesia-buku-online-best-seller2018/\#gref https://www.sastrawan.web.id/sejarah-perkembangan-sastra-indonesia/ https://hot.detik.com/book/d-4308599/nanti-kita-cerita-tentang-hari-ini-laris-terjual-30ribu-eksemplar https://www.gramedia.com/blog/fakta-di-balik-larisnya-buku-nanti-kita-cerita-tentanghari-ini-marchella-fp/\#gref http://www.tribunnews.com/lifestyle/2018/11/14/best-seller-marchella-fp-blak-blakantentang-kisah-dibalik-nanti-kita-cerita-tentang-hari-ini?page $=2$ https://www.iep.utm.edu/ricoeur/ https://kinibisa.com/artikel/detail/musik-kesenian/subdetai/dasar-dasardrama/read/jenis-jenis-drama-berdasarkan-penyajian-cerita https://m.utakatikotak.com/kongkow/detail/5182/Mengenal-Karya-Sastra-Puisi-danJenis-jenisnya https://www.maxmanroe.com/vid/umum/pengertian-prosa.html http://baublogging.com/macam-novel/ http:// ibnuhazm57.blogspot.com/ https://www.academia.edu/24913928/Tiga_Paradigma_Utama_dalam_Ilmu_Komunika si_Positivistik_Interpretif_dan_Kritis_ https://idtesis.com/metode-deskriptif/ https://www.dkampus.com/2017/06/metode-penelitian-jenis-pendekatan/ http://repository.usu.ac.id/bitstream/handle/123456789/38405/Chapter\%20II.pdf;jsessio nid=76B35105C5DF99B5A67713D6E7E7FBDE? sequence $=3$ https://www.kompasiana.com/nailun.izza/552ae95bf17e61f352d623ba/bedapositivisme-vs-konstruktivisme 